Veciana, Stella.

Profesora, Lüneburg Universität, Lüneburg/Alemania, Instituto para ética e investigación

transdisciplinaria para la sostenibilidad.

\title{
Espacios de memoria virtual como laboratorios de investigación artística.
}

\section{Virtual memory environments as laboratories for artistic research.}

TIPO DE TRABAJO:

Comunicación

PALABRAS CLAVE:

Investigación científico-artística, laboratorios a/sincrónicos y virtuales, archivo digital dinámico, selección y toma de decisión de datos, memoria social, sostenibilidad.

KEY WORDS:

Art-sci research, a/synchronous and virtual laboratories, dynamic digital archive, data selection and decision-making, social memory, sustainability.

RESUMEN.

Esta comunicación hace una reflexión teórica sobre metodologías artísticas en la generación de 'espacios de memoria en línea', la influencia de códigos y valores culturales sostenibles en estos espacios y expone dos casos particulares de archivos digitales dinámicos en el contexto de conferencias científicas para la sostenibilidad y de una biblioteca pública como ejemplos de laboratorios de investigación científico-artística de tipología a/sincrónica y de tipología virtual.

El archivo clásico analógico pasa del espacio del museo a la memoria dinámica en redes de bancos de datos hasta nuevos entornos híbridos de realidades mixtas. ¿En qué se diferencia el modelo de archivo moderno como la biblioteca presencial de los modelos de archivo de bases de datos y su conectividad por las tecnologías de Internet? ¿Cómo se caracteriza la memoria social que se sirve de sistemas de base de datos interactivas? Los 'espacios de memoria online' transforman el concepto de archivo, que cumplía funciones de conservación de patrimonio cultural, para convertirse asimismo en centro de producción estético-científica como en los experimentos de participación colectiva en 'monumentos virtuales' que activan procesos de memoria social.

Sobre la base de esta transformación histórica y enfoques metodológicos artístico-científicos interculturales el objetivo de la comunicación será presentar el espacio de la memoria dinámica online como laboratorios futuros de investigación científicoartística. 


\section{ABSTRACT.}

This paper makes a theoretical reflection on artistic methodologies in the generation of 'online memory environments', the influence of cultural codes and values of sustainability in these spaces and exposes in particular two cases of dynamic archives within the context of scientific conferences for sustainability and a public library as examples of two typologies of laboratories of artistic-scientific research: the a/synchronic and the virtual.

The classic analogue archive passes from the museum space to databank networks based on dynamic memory to new hybrid environments of mixed realities. How does the modern archive model differentiate as the on-site library of database from databank archive model? How do interactive database systems influence social memory? The 'online memory environments' transform the concept of the archive, which served to preserve cultural heritage, becoming as well a laboratory of aestheticscientific production as in experiments of collective participation in 'virtual monuments' that activate processes of social memory.

On the basis of this historical transformation and intercultural artistic-scientific methodological approaches, the purpose of this communication is to present the online dynamic memory space as future laboratories of artistic-scientific research. 